\title{
Growth performance of olive barb Puntius sarana (Hamilton, 1822) in response to use of different supplementary feeds during high density rearing of spawn to fry stage
}

\author{
P. C. DAS, J. K. JENA*, BABITA PATRO AND S. S. MISHRA \\ ICAR-Central Institute of FreshwaterAquaculture, Bhubaneswar - 751 002, Odisha, India \\ Indian Council of Agricultural Research, Fisheries Division, Krishi Anusandhan Bhawan - II, Pusa \\ New Delhi - 110 012, India \\ e-mail:pratapcdas@yahoo.com
}

\begin{abstract}
Rearing of olive barb spawn at high stocking density $\left(2400 \mathrm{~m}^{-2}\right)$ was carried out for one month in large concrete seed rearing tanks having soil base. The spawn were fed with three feed combinations (treatments) namely, T1: groundnut oil cake + rice bran at 1:1, T2 : ground nut oil cake + rice bran + fish meal at 40:40:20 and T3 : Soyamilk + egg custard. After 30 days rearing, T2 showed approximately 20\% higher survival than T1 (50.5 $1.9 \%)$, whereas the survival was significantly lower in T3 $(43.2 \pm 5.2 \%)$. In T2, the fry showed a clear edge in growth within 10 days of rearing, which continued further to register 24 and $47.3 \%$ higher weight over T1 and T3 respectively, after 30 days. Higher survival, final body weight as well as biomass yield in T2 over T1 revealed requirement of additional animal protein (fish meal) in the diet for better nourishment of olive barb in nursery phase. But in T3, despite presence of soybean and egg protein, fry showed poor survival (43\%) and growth, indicating unsuitable or inadequate nutrient supplementation through this diet as compared to the other two.
\end{abstract}

Keywords: Fry, Growth, High density rearing, Nursery, Olive barb, Survival

\section{Introduction}

The olive barb Puntius sarana (Hamilton) has been identified as a potential cultivable species for inclusion into the species spectrum of freshwater aquaculture in India (Gopakumar et al., 1999; Chakraborty et al., 2005; Jena et al., 2008). During last decade, propagation of this species through aquaculture has helped in its restoration from 'vulnerable' status (Mahanta et al., 1994; Mukherjee et al., 2002; Chakraborty et al., 2003) to the status of 'least concerned' as per IUCN Red List of Threatened Species (www.iucnredlist.org). Jena et al. (2007) studied the compatibility of olive barb with the three Indian major carps in grow out system. While they reported it to be compatible with catla, the rohu-olive barb and mrigalolive barb combination yielded more biomass than the rohu-mrigal combination, which prompted them to suggest its suitability to culture with both rohu and mrigal under the polyculture system. Induced breeding technique of the species has been standardised using synthetic inducing agent ovaprim (CIFA, 2007). However, pond rearing of fry and fingerlings of the species has been reported to be marred with problems of heavy mortality (Chondar, 1999), lower growth, survival and susceptibility to diseases and deformities (Chakraborty et al., 2003;
Parvez and Khan, 2005). Jena et al. (2007) reported higher survival in rearing of fry to fingerlings with use of groundnut oil cake (GOC) and rice bran (RB) mixture (1:1) added with 5\% fish meal (FM). In another study on rearing fry to fingerling, Das et al. (2011) reported the fry of olive barb to exhibit higher growth when fed GOC and RB mixture along with live aquatic insects (Notonectids). While these reports suggested probable requirement of animal protein for better nourishment of early life stages of olive barb, no systematic information is available on its nursery rearing. In this context, the present study aimed to evaluate suitability of selected supplementary feeds on growth performance during nursery phase.

\section{Materials and methods}

The spawn rearing study was carried out for 30 days in six concrete tanks ( $10 \mathrm{~m}$ x $5 \mathrm{~m} \times 1.2 \mathrm{~m})$ having $15 \mathrm{~cm}$ thick soil base and filled up to $1 \mathrm{~m}$ water depth. Tank preparation involved use of manures and fertilisers applied at conventional dose (Jena et al., 2009), i.e., $750 \mathrm{~kg}$ of GOC, $200 \mathrm{~kg}$ cow dung and $50 \mathrm{~kg}$ single super phosphate (SSP) per ha in three splits. While the first dose was used three days prior to spawn stocking, the other two splits were used on $8^{\text {th }}$ and $16^{\text {th }}$ day after 
stocking. Each tank was stocked at $2400 \mathrm{~m}^{-2}$ of spawn (24 million $\mathrm{ha}^{-1}$ ). The spawn were fed with three feed combinations (treatments) namely, $\mathrm{T} 1: \mathrm{GOC}+\mathrm{RB}$ at 1:1, T2 : GOC + RB + FM at 40:40:20 and T3 : Soyamilk + egg custard. Two replications were maintained for each treatment. The crude protein content of GOC, rice bran, soybean and FM (anchovy) were: 41.2, 10.8, 42.4 and $61.8 \%$, respectively. Treatment $\mathrm{T} 3$ was included in the study to represent the farmer's practice of nursery rearing of the species. All the feed ingredients in T1 and T2 were powdered to $50-100 \mu$ particle size in a feed mill before preparing the feed mixture. For preparation of soyamilk, overnight soaked soybean was made into paste, added water and filtered through 80 mesh net cloth to collect the milk, while egg custard was made by making paste out of half boiled eggs. The two ingredients were mixed together and diluted with more water before feeding. The powdered feed mixture was dispensed gently over the water surface to ensure floating, while the liquid mixture of T3 was sprinkled uniformly in the tanks.

In $\mathrm{T} 1$ and $\mathrm{T} 2$, daily feed was provided at 200, 300, 400 and $500 \%$ of the initial spawn biomass (1.0 lakh spawn weigh approximately $140 \mathrm{~g}$ ) during $1^{\text {st }}, 2^{\text {nd }}, 3^{\text {rd }}$ and $4^{\text {th }}$ week, respectively. In T3, the daily feed during the $1^{\text {st }}$ week consisted of milk prepared from $200 \mathrm{~g}$ soybean which was mixed with custard of one boiled hen's egg. Quantity of soybean for milk preparation was increased by $50 \%$ in every subsequent weeks $(300,450$ and $675 \mathrm{~g}$ in $2^{\text {nd }}, 3^{\text {rd }}$ and $4^{\text {th }}$ week, respectively), while egg number increased to two per day during $3^{\text {rd }}$ and $4^{\text {th }}$ weeks.

Fish sampling in tanks was carried out at 5 day intervals. Length and weight of 25 fry from each replicate tank were recorded. Sampling of water was also carried out between 07:00 and 08:00 hrs at 5 day intervals to measure the important parameters. While water temperature and $\mathrm{pH}$ were measured in situ, samples were brought to laboratory and analysed for dissolved oxygen (DO, after fixing at the site), total alkalinity (TA), total hardness $(\mathrm{TH})$ and inorganic nutrients viz., total ammonia nitrogen (TAN), nitrite, nitrate and phosphate as per standard methods (APHA, 2005). Fry were harvested after 30 days by repeat netting followed by complete draining. Data were recorded for calculation of the yield attributes. The data on fish growth, survival and biomass production were statistically analysed using PC-SAS program for Windows, release v6.12 (SAS Institute, Cary, NC, USA) and Duncan's multiple range test was performed to compare the growth and yield of the stunted fingerlings.

\section{Results and discussion}

Water temperature in the tanks varied within a narrow range of 29.1-31.8 $\mu$ during the study. Mean
DO concentrations varied in the range $2.29-6.62 \mathrm{mg} \mathrm{l}^{-1}$. There was a marked depletion of DO in almost all the tanks on day 5 (Fig. 1a). At high density, apart from fish respiration, continuous overcast during $3^{\text {rd }}$ to $6^{\text {th }}$ day could be the possible reason for depletion in DO. However, DO level improved later and remained at moderate levels for the rest of the period with no marked fluctuation among the treatments. The water $\mathrm{pH}(7.13-8.82)$ also remained similar among the treatments (Fig. 1b), attributed mostly to the interim liming. Ahmed (1997) reported the need for maintenance of minimum level of water quality such as DO at $5 \mathrm{mg} \mathrm{l}^{-1}, \mathrm{pH}$ at 6.7-8.6 and free $\mathrm{CO}_{2}$ at $<3 \mathrm{mg} \mathrm{l}^{-1}$, ammonia at $<0.02 \mathrm{mg} \mathrm{l}^{-1}$ and alkalinity at above $20 \mathrm{mg}^{-1}$ to maintain fish health. Further for carps, generally DO level of $>3 \mathrm{mg} \mathrm{l}^{-1}$ in the morning hours and fluctuations of diurnal water $\mathrm{pH}$ within a range of 7.5-8.3 are generally considered ideal. In the present study, morning DO (4.4-4.8 $\left.\mathrm{mg} \mathrm{l}^{-1}\right)$ and $\mathrm{pH}$ in tanks were close to the ideal ranges suggested by Ahmed (1997). Total alkalinity and hardness were also above $40 \mathrm{mg} \mathrm{l}^{-1}$ in treatments, indicating prevalence of a good growing environment for the nursery phase (Ahmed, 1997; Basavaraja and Anthony, 1997). Both these parameters showed gradual increase with progress of rearing (Fig. 1c,d), which could be attributed to the cumulative increase of the alkaline earth $(\mathrm{Ca})$ and bicarbonate in water through liming (Boyd, 1990); as well as the increased rate of $\mathrm{CO}_{2}$ production from decomposition of accumulated organic matter such as the 3 split dosages of manure, faeces and excess feed (Knud Hansen, 1998; Thakur et al., 2004). The TAN did not show marked variation during the study period except for a peak on day 30 in all the treatments (Fig. 1e). Though the TAN level, especially on day 30 was much higher than the ideal ammonia level $\left(0.02 \mathrm{mg} \mathrm{l}^{-1}\right)$ suggested by Ahmed (1997), we have not encountered any abnormal behaviour or mortality of fry. T1 showed lower $\mathrm{NO}_{2}-\mathrm{N}$ and $\mathrm{NO}_{3}-\mathrm{N}$ levels than the other two treatments, (Fig. 1f, g) probably due to absence of animal protein in the former. The $\mathrm{PO}_{4}-\mathrm{P}$ showed buildup in the tanks (Fig. 1h), but without any systematic trend.

In general, the observed water quality, without marked variations among the treatments, indicated a uniform growing environment in all the tanks. Further, it also indicated that use of the three different diets did not lead to any marked variation in the water parameters.

Survival is an important consideration for the success of seed rearing. After 30 days of nursery phase, fry survival varied among the diet types with significantly higher survival in T2 (70.2\%) followed by T1 (50.5\%) and T3 (43.2\%) (Table 1). Chakraborty et al. (2003) have reported 49.2 - $62.9 \%$ survival for same species in earthen nursery pond, after six weeks of nursery phase, but at lower 


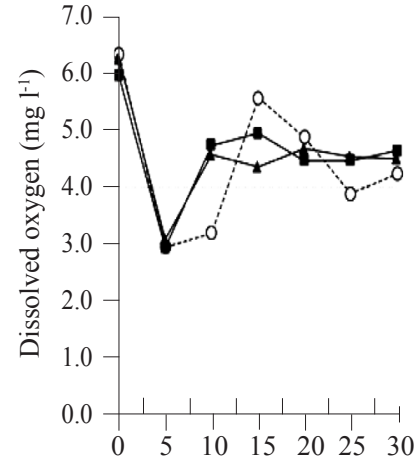

(a)

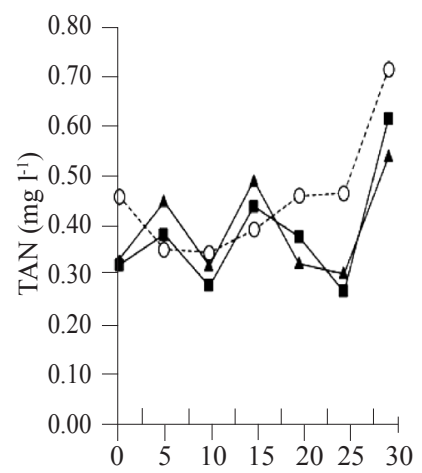

(e)

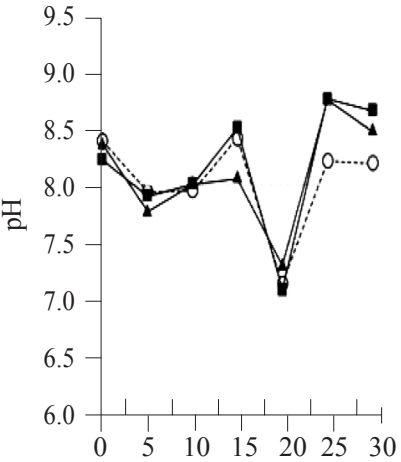

(b)

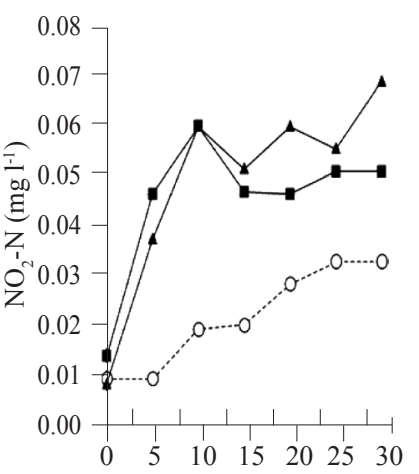

(f)

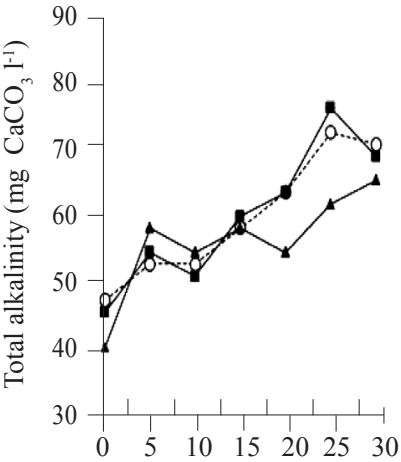

(c)

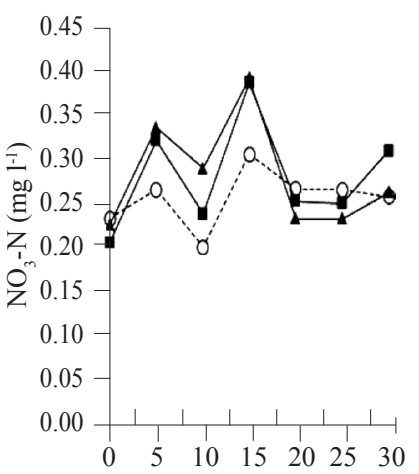

(g)

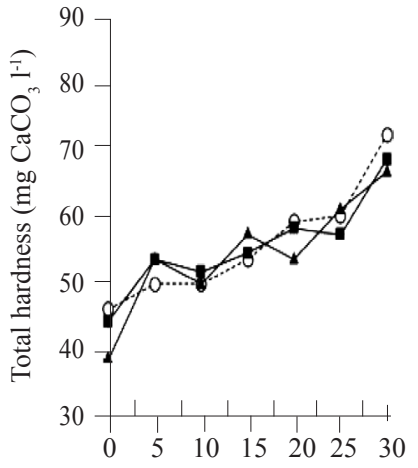

(d)

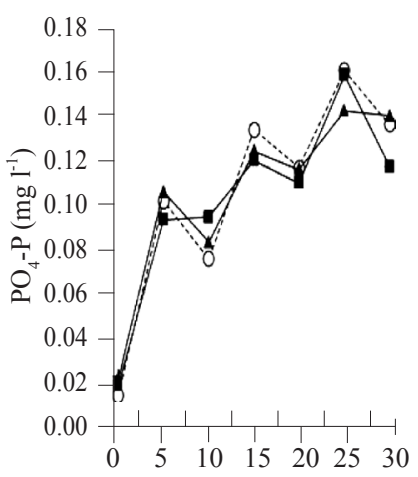

(h)

Days of rearing

$$
-\mathrm{O}-\mathrm{T} 1, \longrightarrow \mathrm{T} 2, \longrightarrow \mathrm{T} 3
$$

Fig. 1. Water quality parameters in the experimental tanks during nursery rearing of olive barb

Table 1. Yield attributes of the fry of $P$. sarana during fry rearing with different feed combinations

\begin{tabular}{llllllll}
\hline Treatment & $\begin{array}{l}\text { Initial length } \\
(\mathrm{mm})\end{array}$ & $\begin{array}{l}\text { Initial weight } \\
(\mathrm{mg})\end{array}$ & $\begin{array}{l}\text { Survival } \\
(\%)\end{array}$ & $\begin{array}{l}\text { Final length } \\
(\mathrm{mm})\end{array}$ & $\begin{array}{l}\text { Final body } \\
\text { weight }(\mathrm{mg})\end{array}$ & $\begin{array}{l}\text { Harvest biomass } \\
\left(\mathrm{kg} \mathrm{tank}^{-1}\right)\end{array}$ & $\begin{array}{l}\text { Harvest biomass } \\
\left(\mathrm{kg} \mathrm{ha}^{-1}\right)\end{array}$ \\
\hline T1 (RB+GOC) & 5.0 & 1.51 & $50.5 \pm 1.9^{\mathrm{b}}$ & $16.27 \pm 1.4^{\mathrm{a}}$ & $45.5 \pm 11.0^{\mathrm{a}}$ & $2.74 \pm 0.56^{\mathrm{b}}$ & $547.9 \pm 112.6$ \\
T2 (RB+GOC+FM) & 5.0 & 1.51 & $70.2 \pm 3.8^{\mathrm{a}}$ & $17.6 \pm 1.0^{\mathrm{a}}$ & $56.4 \pm 4.0^{\mathrm{a}}$ & $4.74 \pm 0.18^{\mathrm{a}}$ & $947.4 \pm 35.7$ \\
T3 (Soyamilk+Egg) & 5.0 & 1.50 & $43.2 \pm 5.2^{\mathrm{c}}$ & $16.1 \pm 1.1^{\mathrm{a}}$ & $38.3 \pm 10.0^{\mathrm{a}}$ & $1.94 \pm 0.30^{\mathrm{c}}$ & $388.4 \pm 60.7$ \\
\hline
\end{tabular}

Values (Mean $\pm S D$ ) bearing same superscripts in a column do not differ significantly $(p>0.05, n=3)$

stocking density of 0.7 - 0.9 million spawn ha-1. However, considering the duration of nursery phase, survival in the present study after 30 days were much closer to the range ( $56-78 \%$ ) reported by Hossain et al. (2007) after 35 days of nursing olive barb fry in laboratory. Compared to these earlier studies, the survival obtained in T1 and T2, despite use of much higher stocking density ( 24 million), can be considered better in terms of number of fry harvested. The results also demonstrated the advantage of using concrete tanks for nursery phase of the species over earthen ponds, attributed to greater control on the water quality and feed management.

Incorporation of fish meal at 20\% level in diet T2 led to approximately $20 \%$ increase $(\mathrm{p}<0.05)$ in the survival compared to control (T1) (Table 1). Though average final body weights $(\mathrm{ABW})$ were similar in treatments, such higher survival in T2 compared to T1 was obviously attributed to inclusion of fish meal, since it was the only variable ingredient between these two treatments. Good availability of plankton, particularly zooplankton is reported to favour better survival and growth during early life stages of the Indian major carps (Chakraborty et al., 2003; Jena et al., 2009). The present study also revealed higher requirement of animal protein for olive barb fry. However, survival in T3 $(43.2 \pm 5.2 \%)$ was significantly lower compared to the other two diets despite high protein contents of the two ingredients. While no earlier report is available on use of this diet for nourishing olive barb spawn to fry stage, the observed survival can be considered as an 
appreciable level in nursery phase, making use of this diet by farmer a feasible option for nursery phase of olive barb.

The spawn fed with diet T2 showed a clear edge in growth (Fig. 2) within 10 days of rearing, which continued further to register 24 and $47.3 \%$ higher weight attainment at the end of nursery phase compared to T1 and T3, respectively (Table 1). Statistically however, there was no significant difference in the average final body weight $(A B W)$ or length $(A B L)$ of the fry in the three treatments $(p>0.05)$, which was probably due to their wide size variation within population of each tank (Table 1). Despite

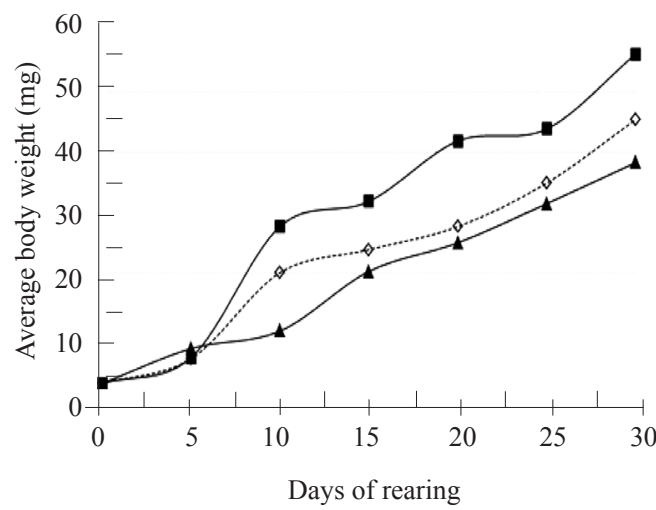

$$
-\infty-\mathrm{T} 1,
$$

nursery phase of carps and barbs (Jena et al., 2009) Plankton concentrations also largely influence the water quality in nursery ponds. Though plankton enumeration has not been done in the present study, prevalence of an almost similar water environment in the tanks across the treatments (Fig. 1 and 2) indicated their undifferentiated influence on the fry growth. So, the varietal growths observed in the fry in treatments revealed significant role of diet type in fry growth realisation in olive barb. While the study revealed advantage of using diet enriched with fish meal for higher survival and growth realisation, the

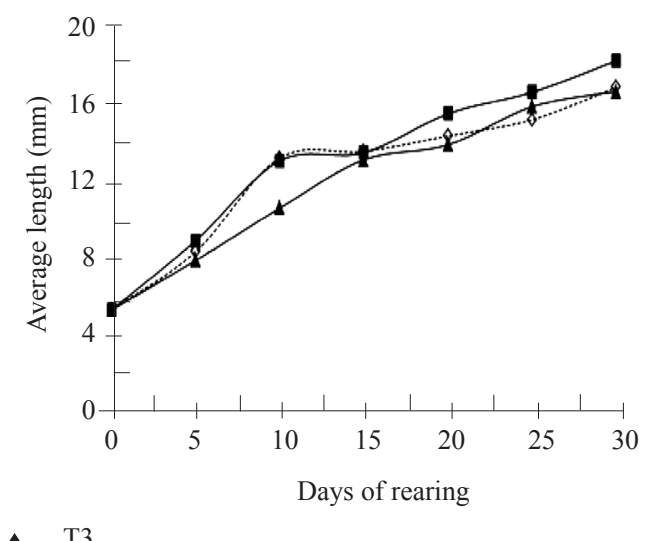

Fig. 2. Growth curve of olive barb fry fed with different diet during the nursery phase

similar harvested size, T2 showed significantly higher biomass yield $(\mathrm{p}<0.05)$ over $\mathrm{T} 1$, attributed to its increased survival, and demonstrated the advantage of fish meal supplementation for fry growth. Further, size variation was minimal in tanks in T2 (lower standard deviation) which implicated more uniform supplementation of nutrient through this diet as compared to the other two. In an earlier study by us on the same species (Das et al., 2011), fry had also shown significantly higher growth when fed with prepared diet along with animal protein (live notonectids) compared to the prepared diet alone, which demonstrated better nutritional supplementation through co-feeding. We have also reported (Das et al., 2011) highly carnivorous behaviour of olive barb during nursery phase. The present result in terms of higher realisation of the survival, harvested body weight as well as biomass yield in T2 also indicated such carnivorous food habit and requirement of additional protein (fish meal) in diet for better nourishment during nursery phase. Whereas, T3 having both soya milk and egg as the protein sources, showed poor fry performance, indicating probable unsuitability or inadequacy of the nutrient supplementation through this diet as compared to the other two diets.

Availability of natural plankton is an important criterion for growth and survival of the fry during the poor show with use of egg and soya milk combination warranted the need to study nutrient supplementation of these feeds and their suitability for olive barb fry.

\section{Acknowledgements}

The authors are grateful to the Director, ICAR-Central Institute of Freshwater Aquaculture, Bhubaneswar, India, for providing financial and logistic support for the study.

\section{References}

Ahmed, A. T. A. 1997. Disease problems in carp and shrimp hatchery. In: Hassan, Rahman and Sattar, M. M. (Eds.), Quality assurance in induced breeding, Department of Fisheries, Jessore, Bangladesh, p. 23-30.

APHA 2005. Standard methods for the examination of water and wastewater, $21^{\text {st }}$ edn. Washington, DC, USA, American Public Health Association, New York.

Basavaraja, N. and Antony, J. M. 1997. Rearing of spawn and fry of Cyprinus carpio on conventional and supplementary feed. Indian J. Fish., 44(2): 165-170.

Boyd, C. E. 1990. Water quality in ponds for aquaculture. Alabama Agricultural Experiment Station, Auburn University, Alabama, $482 \mathrm{pp}$.

Chakraborty, B. K., Miah, M. I., Mirza, M. J. A. and Habib, M. A. B. 2003. Rearing and nursing of local 
Sarpunti, Puntius sarana (Hamilton) at different stocking densities. Pakistan J. Biol. Sci., 6(9): 797-800.

Chakraborty, B. K., Miah, M. I., Mirza, M. J. A. and Habib, M. A. B. 2005. Growth, yield and returns to Puntius sarana (Hamilton) Sarpunti, in Bangladesh under semiintensive Aquaculture. Asian. Fish. Sci., 18: 307-322.

Chondar, S. L. 1999. Biology of finfish and shellfish. SCSC Publishers (India), Howrah, West Bengal, India, 514 pp.

CIFA 2007. Annual report 2006-07. Central Institute of Freshwater Aquaculture, Bhubaneswar, India.

Das, P. C., Jena, J. K., Singh, T. K., Kar, S. and Mitra, G. 2011. Notonectids as live food for olive barb, Puntius sarana: implication for aquatic insect control in carp seed rearing. J.Appl. Aquac., 23:231-237.

Gopakumar, K., Ayyappan, S., Jena, J. K., Sahoo, S. K., Sarkar, S. K., Satapathy, B. B. and Nayak, P. K. 1999. National freshwater aquaculture development plan. Central Institute of Freshwater Aquaculture, Bhubaneswar, India, $75 \mathrm{pp}$.

Hossain, M. I., Khan, M. M. R., Siddik, M. A. B. and Hasan, M. 2007. Effects of feed on survival and growth of local srpunti (Puntius sarana, Hamilton) fry in glass aquaria. J. Bangladesh Agril. Univ., 5(2): 371-376.

Jena, J. K., Das, P. C., Das, B. K., Mohapatra, B. C., Sarangi, N., Modayil, M. J., Vass, K. K., Ravichandran, P., Ponniah, A. G., Syda Rao, G., Eknath, A. E. and Ayyappan, S. 2009. Aquaculture technologies for farmers. Indian Conucil of Agricultural Research, New Delhi, 126 pp.

Jena, J. K., Das, P. C., Das, R. and Mondal, S. 2007. Performance of olive barb, Puntius sarana (Hamilton) in fingerling rearing with rohu, Labeo rohita (Hamilton) and mrigal, Cirrhinus mrigala (Hamilton). Aquaculture, 265: 305-308.

Jena, J. K., Das, P. C., Kar, S. and Singh, T. K. 2008. Olive barb, Puntius sarana (Hamilton) is a potential candidate species for introduction into the grow-out carp polyculture system, Aquaculture, 280: 154-157.

Knud-Hansen, C. F. 1998. Pond fertilization: ecological approach and practical application. Pond dynamics/ aquaculture CRSP, Oregon State University, Corvalis, Oregon.

Mahanta, P. C., Kapoor, D., Dayal, R. and Ponniah, A. G. 1994. Prioritisation of the Indian fish species for conservation. In: Dehadrai, P. V., Das, P. and Verma, S. R. (Eds.), Threatened fishes of India. Natcon Publication, India, p. 379-385.

Mukherjee, M., Praharaj, A. and Das, S. 2002. Conservation of endangered fish stocks through artificial propagation and larval rearing technique in West Bengal, India. Aquac. Asia, 7(2): 8-11.

Parvez, I. and Khan, M. M. R. 2005. Effect of feed on larval rearing of local sarpunti (Puntius sarana, Hamilton) in laboratory condition. Bangladesh J. Fish., 29(1 \&2): 63-68.

Thakur, D. P., Yi, Y., Diana, J. S. and Lin, C. K., 2004. Effects of fertilization and feeding strategy on water quality, growth performance, nutrient utilisation and economic return in Nile tilapia (Oreochromis niloticus) ponds. Aquaculture CRSP 22 $2^{\text {nd }}$ annual technical report. 